\title{
Research Trends in Accounting Fraud Using Network Analysis
}

\author{
So-Jin $\mathrm{Yu}^{1}$ and Jin-Sung Rha ${ }^{2, * \mathbb{B}}$ \\ 1 School of Business, State University of New York, Fredonia, NY 14127, USA; So-Jin.Yu@fredonia.edu \\ 2 School of Business Administration, Dankook University, Jukjeon 16890, Korea \\ * Correspondence: jinsungrha@dankook.ac.kr; Tel.: +82-31-8005-3417
}

Citation: Yu, S.-J.; Rha, J.-S. Research Trends in Accounting Fraud Using Network Analysis. Sustainability 2021, 13, 5579. https://doi.org/10.3390/ su13105579

Academic Editor: Antonio M. López Hernández

Received: 8 March 2021

Accepted: 14 May 2021

Published: 17 May 2021

Publisher's Note: MDPI stays neutral with regard to jurisdictional claims in published maps and institutional affiliations.

Copyright: (C) 2021 by the authors Licensee MDPI, Basel, Switzerland. This article is an open access article distributed under the terms and conditions of the Creative Commons Attribution (CC BY) license (https:// creativecommons.org/licenses/by/ $4.0 /)$.

\begin{abstract}
Accounting fraud is a highly unethical management activity with a significant negative influence on stakeholders, which can harm a firm's long-term sustainability prospects. Given the considerable progress in this field, a comprehensive theoretical organization of the research, along with a trend analysis, are needed. This study employed network text analysis to systematically analyze the research trends in accounting fraud by combining text mining techniques and network analysis. Unlike other studies on research trends that present statistical data by classifying research topics and methodologies, this study formed networks using the trait information of studies, such as "keywords" and "authors", and conducted analyses such as centrality and cluster analyses. These exercises allowed for the identification of key research areas and groups. The results suggest that the literature on accounting fraud was developed based on six keywords: fraud detection techniques, executive compensation, assessments of fraud risks in audit processes, forensic accounting, corporate governance, and various topics related to top management. Overall, authorship analysis suggests that the key cluster contributors are Carpenter, Jones, Brazel, Zimbelman, Cohen, Cumming, Carcello, Kaplan, and Lennox.
\end{abstract}

Keywords: accounting fraud; network text analysis; research trends; sustainable accounting

\section{Introduction}

While ethical and sustainable management have become popular terms in the corporate world, high incidences of accounting fraud exist and have a significant impact on firms across all industries. The Enron Corporation serves as a case in point: once one of the seven largest natural gas trading companies in the United States, it engaged in accounting malpractice involving the deliberate manipulation of financial records to present favorable corporate performance and eventually filed for bankruptcy in 2007. In other words, accounting fraud is a highly unethical management activity with a significant negative influence on stakeholders and can harm a firm's long-term sustainability prospects. Accounting ethics is associated with corporate sustainability, and accounting transparency has become a critical requirement for major companies. However, the management teams of many firms are still tempted to falsify records, multiple cases continuing to be reported as the result of weak corporate governance, management, and sustainable accounting. As for sustainable accounting, our study is indirectly associated with sustainable accounting, given that business organizations' sustainability in economic, social, and environmental impacts can be developed based on the financial accounting reporting [1]. The so-called sustainability accounting framework can then be established based on the financial reporting, given that financial reporting can act as a performance evaluation of sustainability and as a means of communication of accounting information [1]. One of most important attributes of the sustainability accounting framework is "transparency", free from errors and material omission or manipulation of accounting information. We believe that our study is indirectly connected to sustainable accounting, although studies on a link between social and/or environmental factors and accounting fraud are rare. 
Many theoretical and empirical studies have explored why executives engage in financial malfeasance and how such behaviors affect a firm. Accounting fraud research has been conducted in various disciplines and, over the past several decades, many researchers have endeavored to explain the causes and consequences of accounting fraud and published manuscripts in various scholarly journals. These journals cover a variety of topical issues such as corporate governance, auditing, financial reporting, regulation, and fraud examination.

Given the considerable progress in this field, a comprehensive theoretical organization of the research is needed, along with exploring future research topics for accounting scandals using trend analyses. Several studies have reviewed the literature on accounting fraud. For instance, Hogan et al. [2] summarized the findings of financial statement fraud-related articles, identifying the characteristics of fraudulent firms in the context of the fraud triangle, and highlighted the role of auditors in fraud prevention and detection. Trompeter et al. [3] extended this view and focused on fraud in other fields such as criminology, ethics, finance, organizational behavior, psychology, and sociology. Most recently, Amiram et al. [4] included other forms of financial reporting fraud and discussed the main findings and challenges that researchers face. These studies were investigated to include more descriptive and comprehensive approaches by summarizing different methodologies, findings, and motivations of fraud-related articles and to present the authors' insights. Uysal [5] used a similar methodological approach—bibliometric analysis— to our research to examine citation patterns and author influence on accounting ethics research because the methodology is useful for identifying and better understanding trends in business ethics such as moral reasoning in an accounting field. In addition, some research articles have synthesized information from various accounting fraud studies using text mining techniques to detect accounting report fraud by analyzing the clues in the quantitative and qualitative textual information. However, a few researchers have carried out a systematic trend analysis in accounting fraud for exploring changes in emphasis in the research field, future research topics, and research groups. A comprehensive overview of current fraudulent accounting research is needed to integrate the diverse theories and practices of fraud prevention and detection and to explore future research topics. Therefore, the main purpose of this study was to systemically analyze research trends, propose future research suggestions, and find leading research groups in accounting fraud using network text analysis.

This study contributes to the literature as follows. This study not only thoroughly examined academic journals from the accounting fraud literature from causes to consequences, but it also suggests trends in the literature, enabling audiences to better grasp the literature in a comprehensive approach. Second, this study employed network text analysis to systematically analyze the research trends in accounting fraud by combining text mining techniques with network analysis. Prior studies conducted the network text analysis to identify rankings and patterns on accounting academic journals and influential authors, given that these studies systemically calculate the influence of journals and authors using a scientific basis [6,7]. Further, the network text analysis enables researchers to track trends of vast amounts of influence of academic journal publication and authorship compared to traditional review research. The key components of the text form a network of keywords, from which major topics and research clusters are identified based on the positions and link structures of the nodes in the network. Unlike other research trend studies that present statistical data by classifying research topics and methodologies, this study forms networks by using trait information for studies, such as "keywords" and "authors", and conducts a variety of related analyses such as centrality and cluster analyses. These exercises make it possible to identify key research areas and groups.

The remainder of this paper is organized as follows. The following section reviews the existing studies on accounting fraud, and Section 3 introduces the network text analysis. Section 4 presents the findings of the network analysis, while Section 5 explains the implications of the study's results and the scope for future research. We used NetMiner 
4.0 for network analysis. NetMiner has been used in many recent network text analyses, because it allows researchers to explore the network data visually and interactively [8].

\section{Literature Review}

In the accounting literature, fraud refers mainly to financial statement fraud, which can be described to a greater or lesser degree by using various terms such as financial misreporting, financial misconduct, financial misstatement, accounting fraud, accounting irregularities, corporate fraud, and financial fraud. For convenience, we refer to "fraud". Most articles focus on financial statement fraud, as an intentional misstatement made by managers, auditors, and other individuals and/or parties at the expense of shareholders, while other forms of fraud are insider trading and asset misappropriation. Fraud-related research has addressed various issues in explaining the causes, consequences, and detection models [9-11].

Prior studies provide empirical evidence on the determinants of fraud. For example, Dechow et al. [9] explored the reasons why firms perpetuate financial statements in violation of the US Generally Accepted Accounting Principles based on the debt hypothesis and the bonus hypothesis. By using a sample of accounting and auditing enforcement releases (AAERs), they found that firms were more likely to commit fraud when they have higher debts than non-fraud firms and weak corporate governance, as (1) they have a smaller audit committee and (2) were less independent of the board of directors. Significantly, more fraud firms violated their debt covenants compared to non-fraud firms, supporting the debt covenant hypothesis as a strong motivation for fraud.

Gerety and Kenneth [10] suggested that a main cause of fraud could occur because the financial market bears the expensive costs to precisely assess the value of firms' assets. The authors noted that firms with high intangible assets could make it more difficult to value their assets than firms with high hard assets, which can be relatively easily measured. Inevitably, it is hard for the market to catch up to corporate misconduct due to the fact of such high costs of verification.

Giroux [11] discussed the unprecedented large accounting scandals, such as Enron, WorldCom, Tyco, and Adelphia, and factors that they incurred. While greed and hubris are reiterated, the author pointed out that meeting earnings benchmarks, such as meeting analyst forecasts and performance-based executive compensation, could be major new factors that caused scandals.

Other studies indicate that weak corporate governance mechanisms, such as a board of directors and an audit committee, can exacerbate the incidence of fraud. Among others, Beasley [12] highlighted the importance of board independence in preventing financial statement fraud by focusing on the board of directors and audit committees. The found that a higher composition and longer tenure of outside directors can mitigate the likelihood of fraud incidences, while an audit committee does not significantly affect the likelihood of fraud. Further, Beasley et al. [13] investigated corporate governance and fraud types in three unique industries: technology, healthcare, and financial services. They found that fraud occurs more frequently in these three industries than in others and that revenue manipulation is more prevalent in the technology industry. Additionally, they pointed out that the fraudulent firms in financial services are more frequently involved in asset misappropriation. Firms in the technology and financial service industries have weak governance mechanisms and fewer independent directors and committee members in an audit committee. Cohen et al. [14] examined the role of corporate governance in the audit processes and how auditors consider corporate governance mechanisms when they perform an audit. They found that auditors regard top management as a primary representative of corporate governance, which is contrary to the agency theory that views top management as an entity overseen by various governance mechanisms such as a board of directors and an audit committee. Moreover, auditors were found to perceive an audit committee as a weak governance mechanism for effective monitoring. Abbott et al. [15] assumed that an audit committee's effectiveness was based on (1) the committee members' proactive 
attitude towards strong corporate governance (activity) and (2) the role of external audit committee directors, increasing firm reputation by effectively monitoring management and by increasing independence, which is an important factor of whether firms can be subject to an SEC investigation due to the fact of financial misstatement.

Prior studies also concentrated on external audit procedures and/or external auditors. Carcello and Nagy [16] suggested that fraud occurs frequently within the first three years of a contract between an audit firm and a client firm, whereas a longer audit tenure does not necessarily incur fraud. Some studies investigated beneficial ways for auditors to deal with the fraud risk during an audit procedure. In their experiment study, Hoffman and Zimbelman [17] suggested that both strategic reasoning and brainstorming can be useful for external auditors for better fraud detection, while it might be difficult to adjust their standard audit procedure according to fraud risks. Brazel et al. [18] found that fraud firms show a greater gap between financial measure, such as revenue growth, and nonfinancial measure, such as employee growth, than non-fraud firms, suggesting that firms' non-financial performance measures can be a useful red flag for external auditors to assess fraud risks.

Another stream of fraud-related research suggests that fraud transpires because of excessive executive compensation. In this respect, Burns and Kedia [19] examined the effect of CEO compensation packages on accounting statements and found that among the components of CEO compensation, stock option sensitivity to stock prices can incentivize a CEO to misreport at the expense of shareholders. Their study guides future research in that the cost and benefit analysis of a CEO committing fraud should be explained in terms of the substantial costs that arise from misreporting such as labor market penalties. Efendi et al. [20] found that a CEO's deep in-the-money stock option increases the likelihood of accounting restatement, because excess stock option compensation can provide a CEO with the incentive to focus on an increase in short-term stock prices to increase personal wealth. These studies suggest that equity-based compensation can incentivize a CEO to engage in fraud; however, other studies provided counterevidence as follows. Erickson et al. [21] investigated whether the equity incentives of the top five executives contributed to accounting fraud. They found that in comparison between fraud firms and non-fraud firms based on industry, year, and firm size, equity incentives were not significantly associated with the likelihood of fraud. Further, there was no significant evidence that top executives unusually sell off their stocks during the fraud period compared to the matched non-fraud firms. Armstrong et al. [22] found no positive association between a CEOs' equity-based compensation and the likelihood of accounting irregularities after controlling for corporate governance, firm financials, and market-wide characteristics between fraudulent and non-fraudulent firms using propensity score matching. Even so, fewer accounting irregularities occur for higher CEO equity incentives, as opposed to the results of some existing studies $[19,20]$.

Several studies investigated the consequences of fraud by actors such as managers, directors, entities, and even fraudulent firms. Dechow et al. [9] suggested that fraud firms become penalized after fraud was announced to investors, plummeting stock prices, and the increase in the bid-ask spreads supported that fraud firms could experience higher cost of capitals due to the failure of a company's trustfulness. Their study contributes to the literature by explaining why firms commit financial statement fraud based on accounting theory, bonus hypothesis and debt covenant hypothesis, and by identifying the causes and consequences of committing fraud. Farber [23] investigated how fraudulent firms recover credibility from investors and capital markets and found results consistent with the findings of prior studies that weak governance increases the likelihood of financial statement fraud. The author also found that capital markets still question the credibility of fraudulent firms, in that analyst following and institutional holdings remain constant before and after fraud detection. However, these firms take, on average, three years to meet the board composition of outside directors and to overcome the number of audit committees compared to non-fraudulent firms, and their efforts to strengthen corporate 
governance seem to lead to superior stock performance. Graham et al. [24] investigated the consequences of restatement firms regarding bank loan contracts. After restatement announcements, firms bear significant economic costs, pay higher amounts of upfront and annual fees for bank loans, and experience short-term maturity and tighter covenant restrictions. Moreover, after restatement, the number of lenders decreases significantly. Their study focused on debt holders' actions after restatement, while prior studies examined equity holders' actions. Karpoff et al. [25] identified the consequences of firms violating one or more of the three provisions of the Securities Exchange Act of 1934, as amended by the Foreign Corrupt Practices Act of 1977, regarding the accuracy of bookkeeping, adequacy of internal control systems, and transparency of financial reporting without intentional falsification or poor internal control. Their results indicated that managers' financial penalties were significant. Specifically, approximately $93 \%$ of the sample lost their positions, and the majority were forcefully dismissed by the end of the law enforcement period. Approximately $28 \%$ of the participants were subject to criminal charges and penalties. Fich and Shivdasani [26] examined firms subject to shareholders' class action lawsuits and found that there was no necessarily abnormal turnover of outside directors in the fraud firms. In addition, they found that financial fraud significantly affected outside directors as well as the top executives of fraudulent firms during the post-fraud detection period and that outside directors significantly lost their directorships in other firms.

Palmrose and Scholz [27] focused on the association between (non)core earnings restatements, and the likelihood of litigation and monetary penalty. Specifically, they posited that firms with manipulated core components, revenue restatement, that are recurring and permanent are pervasive enough to face lawsuits than firms with manipulated non-core components in the financial statement, which are non-recurring and transitory. Kim et al. [28] suggested that socially responsible firms tend to be less involved in financial misreporting subject to SEC investigations. McNichols and Stubben [29] found that manipulating firms subject to SEC investigations tend to over-invest more than non-manipulating firms, while they curbed overinvestment to meet the efficient investment level during a post-manipulating period. Moreover, one study investigated the role of the press as an informational intermediary to disseminate information on the accounting fraud. Miller [30] found that the press produces public information on the predication of fraudulent firms in their early stages by both directly generating original articles and simply redelivering existing information produced by management and/or other information channels. Further, the author suggested that when the press issues new information based on reporter-generated analysis, it can act as a monitor and become informative for fraudulent firms, while simply re-disseminating existing information is not informative. Schrand and Zechman [31] indicated that overconfident executives are more prone to intentional financial misstatements because of more optimistic biases.

Some studies have tempted to combine various accounting fraud studies using text analysis. Sharma and Panigrahi [32] suggested a comprehensive review of the studies on the application of data mining methodologies to detect accounting fraud. Wang [33] presented a comprehensive overview of the existing literature on data mining algorithms related to the topic of automated accounting fraud. Ramos Montesdeoca et al. [34] carried out text mining to analyze 156 accounting fraud articles published in high-impact journals during the period 2000-2018. They found that the articles can be grouped into five categories: auditors, triangle of the fraud, company organization, psychological aspects, and technologies of the information. Based on systematic literature review, Omair and Alturki [35] indicated that the main data mining techniques used in accounting fraud are artificial neural networks, logistic regression, and support vector machine.

Some studies examined databases used in accounting fraud. Karpoff et al. [36] examined four popular databases: (1) the Government Accountability Office, (2) Audit Analytics, (3) the Stanford Securities Class Action Clearinghouse database of securities class action lawsuits, and the Securities and Exchange Commission's Accounting and Auditing Enforcement Releases, and suggested implications for choosing proxies and databases for 
different empirical tests. Donelson et al. [37] documented that how the use of both private enforcement actions and public enforcement actions can affect research implications for accounting fraud.

\section{Network Text Analysis}

This study used network text analysis to understand the research trends in accounting fraud. While existing studies have classified research based on research topics, theory, and methodology and presented the results of descriptive analyses, the network analysis approach allows for an exploratory identification of research trends using "keywords", "authors", and "abstracts", which are representative of the analyzed studies. The network analysis breaks the text down into key components, the results thus not being based on the subjective viewpoint of the researcher while also allowing for the analysis of semantics embedded within the text. The text for analyses is usually quite extensive, as it comes from research papers, news articles, speeches, and reports. However, this study focused on analyzing research papers related to accounting fraud.

Network analysis is used in accounting research to analyze the research trend. Worrel et al. [38] provided a systematic review of accounting information system research using network analysis. They constructed author network and analyzed aspects of network structure based on betweenness, closeness, and degree centrality. Wakefield [7] built the accounting journal network to measure each journal's contribution to the context of accounting research using network diagram. Euske et al. [39] constructed a network based on a citation matrix, which is a proxy for research collaborations among authors. They assessed the relationship among researchers in managerial accounting based on network density and centrality analysis.

The analysis requires the construction of a network composed of links that connect the different nodes. In the analysis of research trends, keywords, authors, and research papers are generally used as network nodes.

Typically, to construct a keyword network, frequently occurring keywords are extracted from the study abstract or keywords. This study utilized the keywords created by the author(s) to extract keywords from the abstract that presented term frequency-inverse document frequency, which means that frequently occurring words from the text may not be significant. For example, words such as "analysis" and "results" appear frequently in the abstracts of papers but are not representative of the study. By contrast, the keywords proposed by the author(s) tend to be more representative of the research topic. Therefore, the keyword network can be viewed as a network of research topics and is widely used to identify related trends. The author network includes all authors as nodes. The analysis of this network allows for the most influential researchers and research groups in a research topic to be identified in order to understand how the research area has developed. Understanding how research groups have contributed to developing research topics allows the analysis of research trends, while constructing a network using papers as nodes allows the analysis of the citation network. The research paper nodes referenced by a referencing node (paper) define the link direction. The citation network allows for co-citation and PageRank analyses, thus enabling the selection of research papers that are essential to a research topic.

However, this study investigated research trends by constructing networks with keywords and authors as nodes. The network analysis process can be described as follows. First, keywords (or authors) were matched with research papers to create a two-mode network. The links in the two-mode network were directionless and connected the keywords (or authors) to the research papers. One research paper node was associated with multiple keyword (or author) nodes. The research paper nodes were not connected to the links and neither were the keyword (or author) nodes, making it challenging to analyze research trends using the two-mode network. It was thus necessary to construct networks of keywords (or authors) for the centrality and cluster analyses. 
Second, the two-mode network of research articles and keywords (or authors) was converted to a one-mode network of keywords (or authors). The basic principle of the one-mode network conversion is as follows. In a two-mode network scenario, where paper " $\mathrm{A}$ " is connected to keywords "a", "b", "c", " $d$ ", and "e", and paper "B" is connected to keywords " $\mathrm{d}$ ", " $\mathrm{e}$ ", " $\mathrm{f}$ ", and " $\mathrm{g}$ ", keywords " $\mathrm{d}$ " and " $\mathrm{e}$ " are reoccurring and can be viewed as related to each other. In other words, the co-occurrence of keywords (or authors) in multiple papers implies a strong correlation between them. The extent of the occurrence is estimated using cosine similarity, the values of which can be used to connect the keywords (or authors) with directionless nodes, thus creating a one-mode network composed of only keywords (or authors).

Third, this study utilized a one-mode network to analyze centrality and identify the influence of individual keywords and authors. The node with the highest activity had a high centrality degree; if it actively connected other keywords (or authors), it had a high betweenness centrality value and could be described as having large scalability. Furthermore, the cluster structure was used for clustering. Keywords of the same cluster signified a specific research area, while author clusters signified research groups.

This study analyzed papers published in international journals to understand the research trends in accounting fraud. Scopus, a leading global academic journal database created by Elsevier in 2004, was used to search for papers. Scopus is increasingly used in research trend analysis, because it is the largest abstract and citation database in the field of management and social science, and offers comprehensive functions to synthesize bibliometric data [40-42]. We searched for "accounting fraud" and "fraudulent accounting" keywords in all journals indexed in Scopus, identifying 932 papers as final analysis targets.

The network text analysis steps used for analyzing accounting fraud research trends are summarized in Table 1.

Table 1. Method used for network text analysis.

Steps

1. Selection of database and articles

- Database: Scopus (2002-2020)

- Searching words: "accounting fraud" and "fraudulent accounting"

- Refining keywords: the reliability of keyword refinement was confirmed by consulting two

- Researchers in the management sector

2. Building a two-mode network (nondirectional)

- Relationship between research paper nodes and keyword nodes (or researcher nodes)

3. One network transformation using inner product or cosine similarity

- Built by keyword nodes (or researcher nodes)

4. Network analysis

- Centrality: degree and betweenness centrality

- Clustering analysis (community analysis)

\section{Results}

\subsection{Subjects}

As previously mentioned, this study used the Scopus academic database to search for research articles on accounting fraud. "Accounting fraud", "accounting scandals", "fraud accounting", and "fraudulent accounting" were selected as searched keywords because most previous research on accounting fraud suggested these keywords. We only included research papers published in English and excluded books and proceedings; this process yielded 932 research papers.

As per Figure 1, papers on accounting fraud began to surface in the 2000s and have been published continuously to date. In the early 2000s, corporate governance and the various risk assessments of accounting fraud were considered mainstream. Church et al. [43] 
examined the factors that affected internal auditors' considerations of financial reporting fraud, and Saksena [44] discussed the internal and external environmental factors that lead to fraud. From 2003 to 2005, many studies related to the determinants and risks of fraud commission and consequences of fraud detection were published [23,45-52].

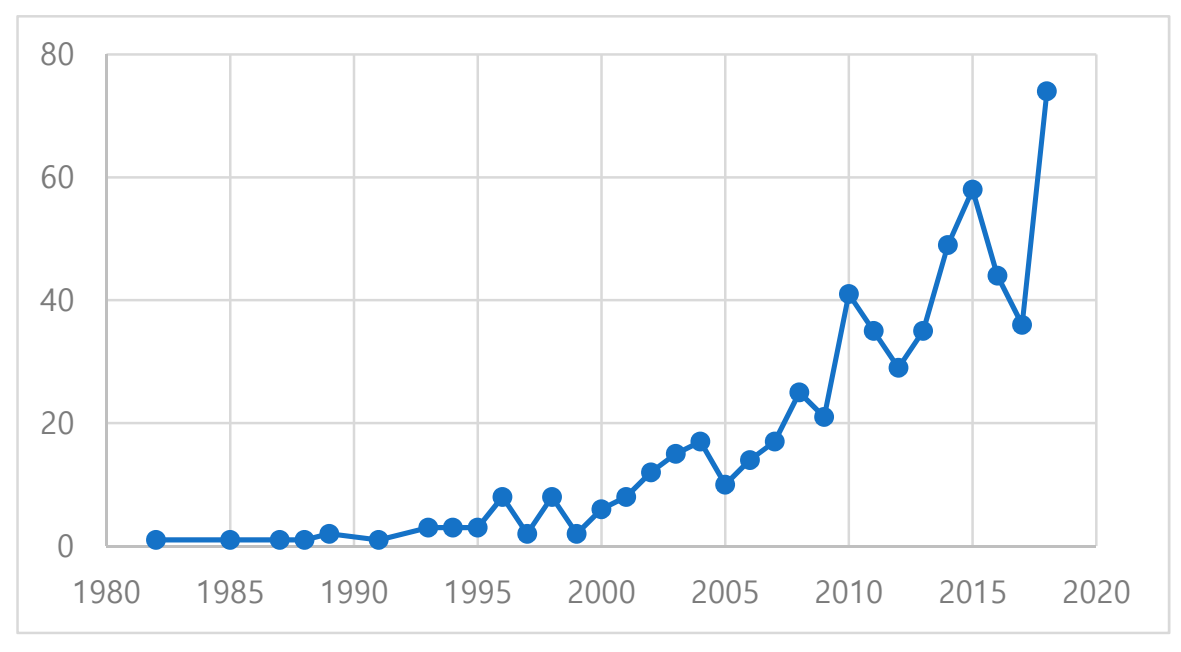

Figure 1. Articles by year.

In the late 2000s, many studies from various stakeholders, such as legislators and directors as well as auditors, executives (CEOs and/or CFOs), directors, and whistleblowers, have been published $[21,26,53,54]$. Subsequently, many research papers have been published, which indicates an increasing trend. As a result, research topics have become more specific and specialized with an increase in corporate social responsibility [55-58]. The main journals that published these papers are the ones listed in Table 2.

Table 2. Articles by journal.

\begin{tabular}{cc} 
Journal & Number of Articles \\
\hline Journal of Business Ethics & 57 \\
Managerial Auditing Journal & 57 \\
Accounting Review & 53 \\
Issues in Accounting Education & 37 \\
Journal of Accounting Research & 28 \\
Auditing & 27 \\
Contemporary Accounting Research & 24 \\
Journal of Financial Crime & 24 \\
Critical Perspectives on Accounting & 18 \\
Journal of Financial Economics & 14 \\
Accounting Horizons & 13 \\
Journal of The International Academy for Case Studies & 13 \\
International Journal of Accounting Information Systems & 12 \\
Current Issues in Auditing & 11 \\
Journal of Accounting and Economics & 10 \\
Journal of Accounting Education & 10 \\
Journal of Corporate Finance & 10 \\
Federal Register & 9 \\
Academy of Accounting and Financial Studies Journal & 9 \\
Accounting, Organizations and Society & 9 \\
Accounting and Finance & 9 \\
International Journal of Financial Research & 9 \\
Journal of Accounting and Public Policy & 9 \\
Review of Accounting Studies & 9 \\
\hline
\end{tabular}




\subsection{Keyword Analysis}

4.2.1. Keyword Analysis for Papers Published: 2002-2014

This study created a two-mode network composed of keywords from 932 papers. In constructing the two-mode network, we only considered the keywords presented by the authors that occurred more than twice in the articles. Researchers often use different keywords with the same meaning such as "accounting fraud" and "fraudulent accounting". To ensure the representativeness of keywords, we consulted two accounting experts and conducted a keyword unification process to eliminate synonymous keywords.

As the importance of business intelligence systems, information technology (IT) on accounting information systems (AIS), and IT audit $[59,60]$ were found to increase since 2015, we analyzed the keywords based on two periods: 2014 and before and from 2015 to 2020 .

A word cloud, as seen in Figure 2, was created using the frequency of the keywords using the manuscripts published in 2014. Larger keywords indicate a higher frequency. There is no relative significance to the location of a keyword on a word cloud. "Financial reporting", "auditing", and "corporate governance" were identified as the most frequently occurring keywords. We distinguished auditing from corporate governance because the former accounts for a major school of thought in the literature, while the latter constitutes internal and external corporate governance mechanisms, other than external auditors. Cosine similarity was calculated to form a one-mode network composed of only keyword nodes. The cut-off value of the cosine similarity was 0.1 , and the formula we used was:

$$
\text { Cosine Similarity }=\frac{\sum_{k=1}^{n} C_{i k} C_{j k}}{\sqrt{\sum_{k=1}^{n} C_{i k}^{2}} \sqrt{\sum_{k=1}^{n} C_{j k}^{2}}}
$$

where $C_{i}$ is the appearance frequency of keyword $i, C_{j}$ is the appearance frequency of keyword $j$, and $k$ represents each research paper.

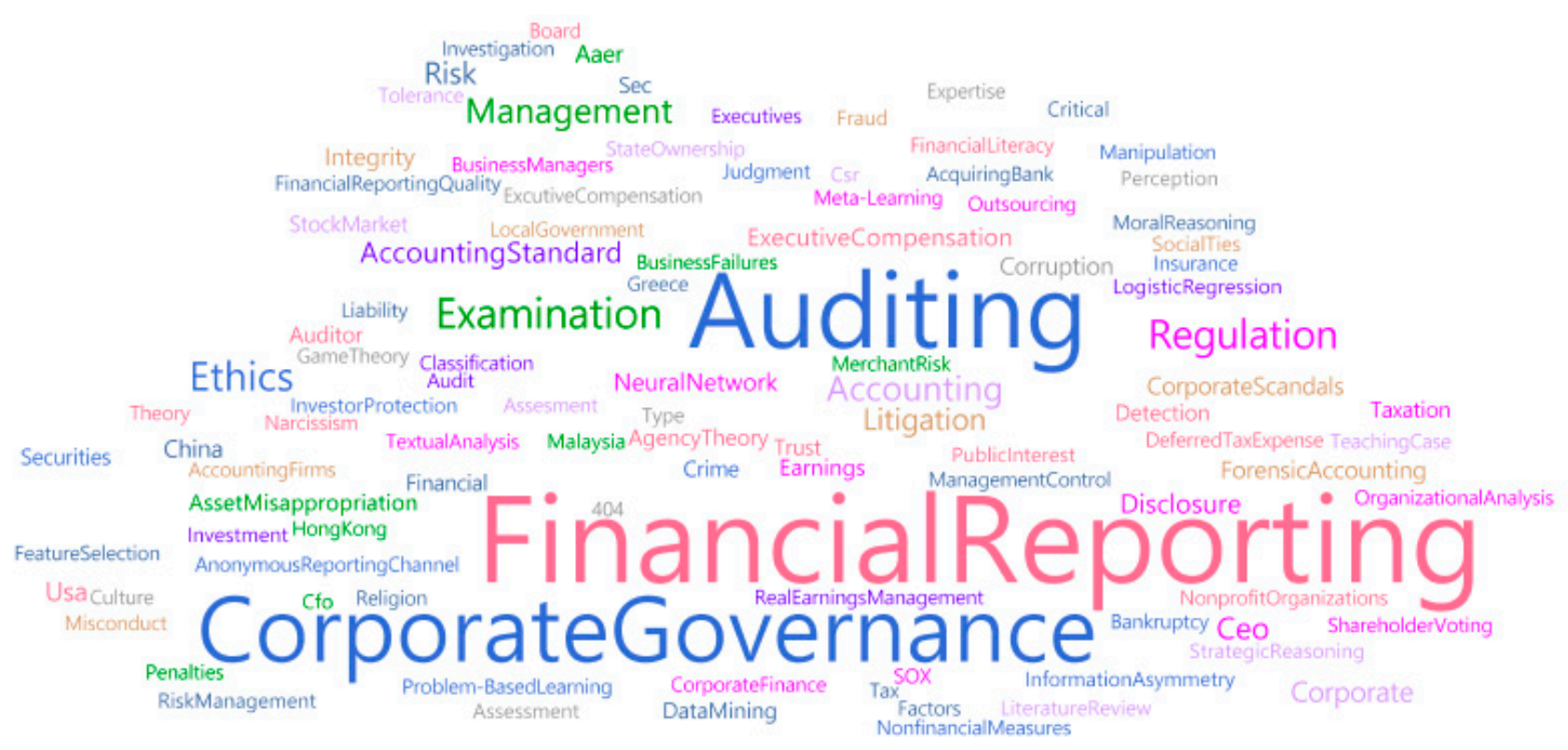

Figure 2. Word cloud (2014 and before).

In a network diagram, nodes represent each research article's keywords or authors. A link in a network is one of the connections between the nodes. There was no directionality in the links between the nodes in this study. Figure 3 illustrates the one-mode network from 2002 to 2014. The keyword node locations in Figure 3 are not significant. The keyword nodes that are connected with links and those that are highly correlated are located closer 
to each other. Figure 3 shows that many keywords are close to one another on the keyword network, while some keywords, such as "misconduct" and "moral reasoning", are isolated on the keyword network, which shows that they were quite heterogeneous from those of other keywords. The network diagram was constructed using NetMiner 4.0 and is called a Spring Map according to the approach of Kamada and Kawai [61].

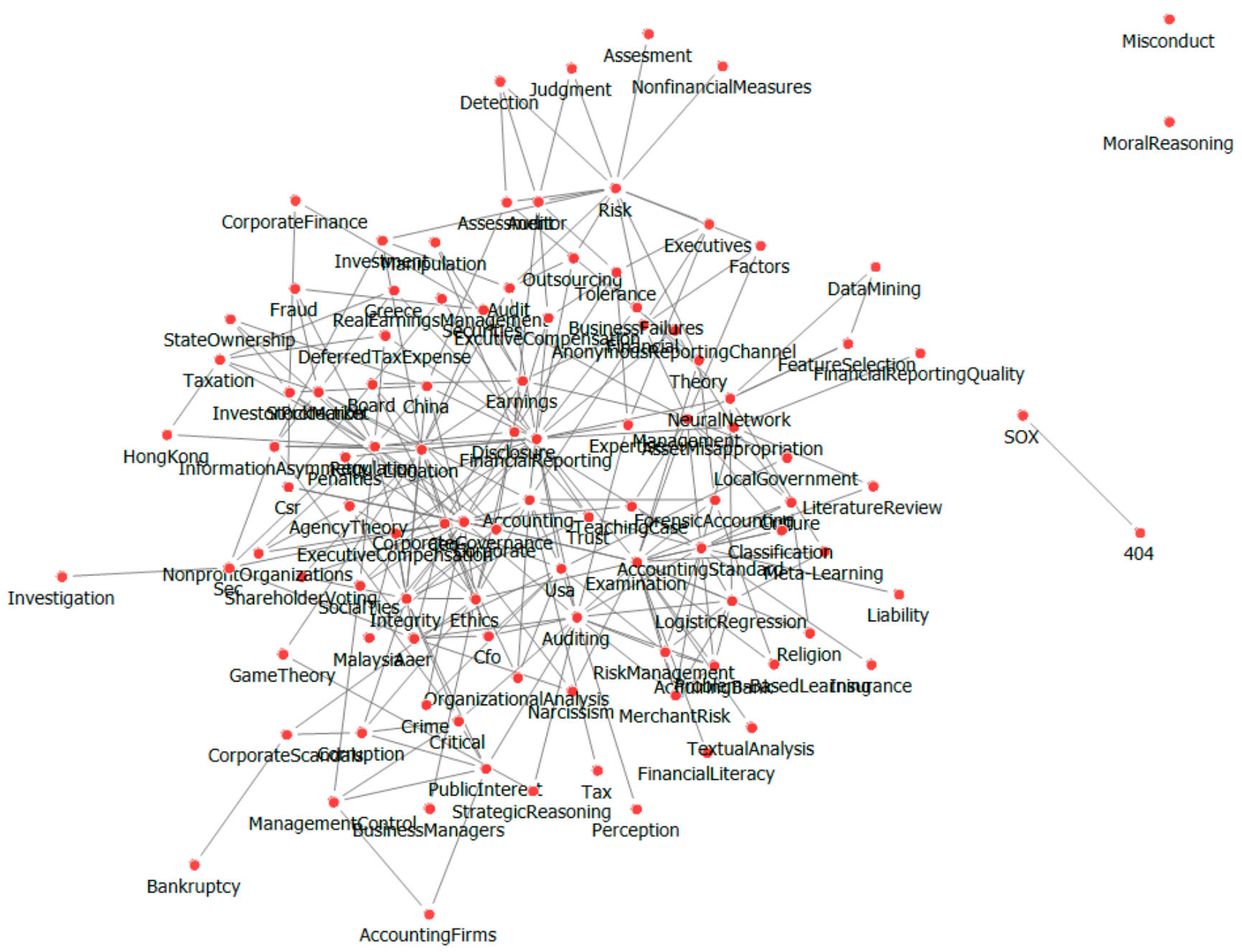

Figure 3. Keyword network (2014 and before).

We also conducted a centrality analysis to identify the most actively researched topics, which expanded the research field. For this analysis, we measured the degree centrality and betweenness centrality. Degree centrality calculates the extent to which a node is connected to other nodes via links in the network:

$$
\text { Degree Centrality }=\frac{\sum \text { Weight of Incident Links }}{\text { Number of Nodes }-1}
$$

Betweenness centrality depicts the extent to which a specific node serves as a medium for the other nodes. Although the degree centrality of a node may be low, if it is linked with nodes with high degree centrality values, it can result in a high betweenness centrality value. Therefore, nodes with high betweenness centrality values connect node groups:

$$
\text { Betweenness Centrality }=\frac{\sum_{j<k} g_{j k}\left(n_{i}\right) / g_{j k}}{\left[\frac{(g-1)(g-2)}{2}\right]}
$$


where $g_{j k}$ is the number of shortest paths between nodes $j$ and $k, g_{j k}\left(n_{i}\right)$ is the number of shortest paths between nodes $j$ and $k$ that contain node $i$, and $((g-1)(g-2) / 2)$ shows how many node pairs do not contain $n_{i}$.

Tables 3 and 4 report the degree centrality and betweenness centrality results from 2002 to 2014, respectively. "Financial reporting", "Fraud examination", "Corporate governance", "Regulation", and "Accounting standard" are the primary subtopics explored in the past. For betweenness centrality, the major subtopics linked to various subtopics are "Financial reporting", "Fraud examination", "Corporate governance", "Auditing", and "Regulation". Despite the slight differences in ranks, the results are similar between degree centrality and betweenness centrality. This implies that the major keywords in most studies on fraud research overlap, and since financial statement fraud is related to financial reporting, it is a violation of the securities law (Regulations) and involves top management and/or boards of directors (Corporate governance) and external auditors (Auditing). The lower values of degree centrality and betweenness centrality show some distinction between the two measures. In degree centrality, the major keywords following "Auditing" are "Risk", "Litigation", "Integrity", "CEO", "Management", "Ethics" among others. Regarding betweenness centrality, the major keywords after "Regulation" are "Accounting Standard", "Risk", "Ethics", "Disclosure", "Litigation", "Accounting", "Management", and others.

Table 3. Degree centrality results (2014 and before).

\begin{tabular}{cc}
\hline Keyword Node & Degree Centrality \\
\hline Financial Reporting & 0.211538 \\
Fraud Examination & 0.201923 \\
Corporate Governance & 0.192308 \\
Regulation & 0.163462 \\
Accounting Standard & 0.153846 \\
Auditing & 0.153846 \\
Risk & 0.125 \\
Litigation & 0.125 \\
Integrity & 0.115385 \\
CEO & 0.105769 \\
Management & 0.105769 \\
Ethics & 0.105769 \\
Accounting & 0.105769 \\
USA & 0.096154 \\
Disclosure & 0.096154 \\
Earnings & 0.076923 \\
AAER & 0.076923 \\
Executive Compensation & 0.076923 \\
\hline
\end{tabular}

Table 4. Betweenness centrality results (2014 and before).

\begin{tabular}{cc}
\hline Keyword Node & Node Betweenness Centrality \\
\hline Financial Reporting & 0.210838 \\
Fraud Examination & 0.174484 \\
Corporate Governance & 0.122679 \\
Auditing & 0.110125 \\
Regulation & 0.08757 \\
Accounting Standard & 0.083437 \\
Risk & 0.071468 \\
Ethics & 0.070172 \\
Disclosure & 0.064762 \\
Litigation & 0.062083 \\
Accounting & 0.057963 \\
Management & 0.056353 \\
USA & 0.030443 \\
CEO & 0.030278 \\
Integrity & 0.029668 \\
Fisappropriation & 0.028028 \\
Asset & 0.024575 \\
Neural Network & 0.024154 \\
China & 0.023409 \\
\hline
\end{tabular}


Table 5 presents the results of cluster analysis from 2002 to 2014.

Table 5. Clustering analysis results (2014 and before).

\begin{tabular}{|c|c|c|}
\hline & Keyword & Description \\
\hline Cluster 1 & $\begin{array}{c}\text { Neural network, logistic regression, } \\
\text { meta-learning, textual analysis, and data mining }\end{array}$ & $\begin{array}{c}\text { Cluster } 1 \text { focuses on fraud detection techniques. Especially, } \\
\text { highly cited papers discuss the effectiveness of neural } \\
\text { network and data mining techniques to detect financial } \\
\text { statement errors }[62,63] \text {. }\end{array}$ \\
\hline Cluster 2 & CEO, AAER, narcissism, SEC, and penalties & $\begin{array}{c}\text { Cluster } 2 \text { centers on the effect of CEO narcissism on } \\
\text { accounting fraud. This line of research focuses on } \\
\text { identifying top executives' individual attributes as fraud } \\
\text { determinants [64]. }\end{array}$ \\
\hline Cluster 3 & $\begin{array}{l}\text { CSR, real earnings management, and } \\
\text { investor protection }\end{array}$ & $\begin{array}{l}\text { Cluster } 3 \text { discusses how corporate social responsibility } \\
\text { affects the various forms of financial reporting [28]. }\end{array}$ \\
\hline Cluster 4 & $\begin{array}{l}\text { Auditor, tolerance, expertise, judgment, and } \\
\text { problem-based learning }\end{array}$ & $\begin{array}{c}\text { Cluster } 4 \text { represents auditor, tolerance, expertise, and } \\
\text { problem-based learning. }\end{array}$ \\
\hline Cluster 5 & $\begin{array}{l}\text { Audit, assessment, non-financial measure, } \\
\text { strategic reasoning, and detection }\end{array}$ & $\begin{array}{l}\text { Cluster } 5 \text { represents the studies on auditors' efforts on fraud } \\
\text { risk in the audit process. Specifically, strategic reasoning } \\
\text { and brainstorming are used. }\end{array}$ \\
\hline Cluster 6 & Social ties, accounting firms, and corruption & $\begin{array}{c}\text { Cluster } 6 \text { includes social ties among directors, } \\
\text { and corruption. }\end{array}$ \\
\hline
\end{tabular}

By applying clustering analysis, this study confirmed whether groups were formed between the research topics. We utilized the community analysis method provided by NetMiner 4.0 [65].

The keyword network analysis resulted in a total of six clusters. Cluster 1 includes major keywords that represent fraud-detection techniques: neural network, fuzzy logic, logistic regression, meta-learning, data mining, and business intelligence. Based on these keywords, Cluster 1 represents studies related to fraud detection techniques to identify fraud risk factors or alleged red flags. Traditionally, existing studies have applied various types of detection tools, including financial ratios, such as liquidity, efficiency, and profitability, using numbers on financial statements and/or logistic regression [66]. Additionally, many studies developed improved models using data mining such as various types of neural networks, meta-learning, discriminant analysis [62]. Green and Choi [63] suggested that neural networks can detect fraudulent errors in financial statements by simultaneously investigating any changes in the relationships among multiple account balances. Lin et al. [67] showed that, among various neural networks, integrated fuzzy neural networks outperform other detection techniques and artificial neural networks. Abbassi et al. [68] documented that the meta-learning approach and machine learning in business intelligence approaches are especially useful in detecting red flags in financial statements by capturing complex contexts and vague nuances. Cluster 2 consists primarily of studies focusing on CEOs. Major keywords include "CEO", "AAER", "narcissism", "SEC", and "penalties". Prior studies identified the individual characteristics, styles, and attributes of CEOs and their impact on accounting fraud. Highly narcissistic CEOs can make bold decisions that are detrimental to companies. Eventually, these CEOs show a positive association with accounting fraud [64]. In Cluster 3, the keywords are corporate social responsibility (CSR), real earnings management, and investor protection. Socially responsible firms are negatively associated with firms' accrual earnings management and real earnings management and are subject to a lesser degree to accounting, auditing, and enforcement releases (AAERs) [28]. Cluster 4 represents auditor, tolerance, expertise, and problem-based learning. Carcello et al. [45] suggested that high industry expertise for auditors can significantly reduce the occurrence of fraud. In Cluster 5, one study conducted an experimental analysis to increase auditors' awareness of the importance of fraud risk. Us- 
ing strategic reasoning and brainstorming, the study confirmed that these two techniques can help auditors conduct better audit procedures in terms of fraud risk [17]. Cluster 6 shows that the social ties among the board of directors inside and outside firms can significantly affect earnings management. Directors showing high earnings management in firms can influence other firms as directors [69].

Overall, our cluster analysis suggests that the literature on accounting fraud was developed based on six keywords: fraud detection techniques, CEO attributes, assessments of fraud risks in audit processes, forensic accounting, corporate governance, and various topics related to top management. The cluster analysis can coincide with early prior studies in the literature, focusing on determinants of accounting fraud, such as weak corporate governance [9,10], audit procedures [16], and executive attributes [31], in early 2000s.

\subsubsection{Keyword Analysis for Papers Published: 2015-2020}

In Figure 4, a word cloud using the frequency of the keywords according to published manuscripts between 2015 and 2020 is shown. "Financial reporting", "Auditing", and "Corporate governance" are the most frequently occurring keywords. Interestingly, during this period, "Forensic accounting", "Fraud risk", and "Fraud triangle" were also frequent. Figure 5 illustrates the one-mode network from 2015 to 2020. Cosine similarity was calculated to form a one-mode network composed of only keyword nodes. The cut-off value of the cosine similarity was 0.1 . A few keyword nodes were isolated on the keyword network, and the keyword nodes were closer on the keyword network compared to the network map in Figure 3. This shows that interrelations among accounting fraud research keywords have strengthened over time.

Similar to the keyword analysis from 2002 to 2014, "Auditing," "Financial reporting", "Corporate governance" and "Fraud examination" were the top keywords. Moreover, some new topics were identified such as the fraud-detection-related keywords: "Fraud risk", "Fraud triangle", "Data mining", "Machine Learning", and "Big data". Table 6 shows the keyword frequencies from 2015 to 2020.

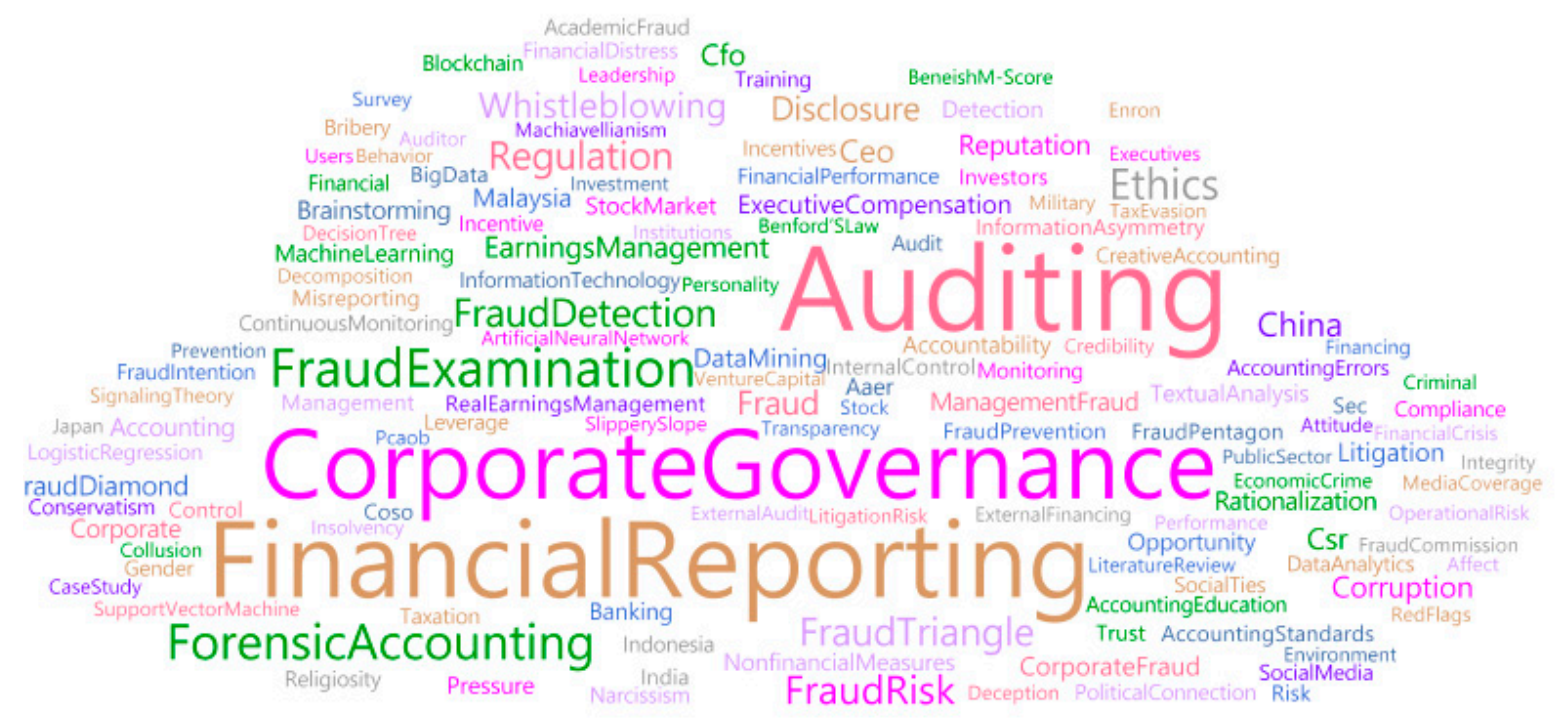

Figure 4. Word cloud (papers published 2015-2020). 


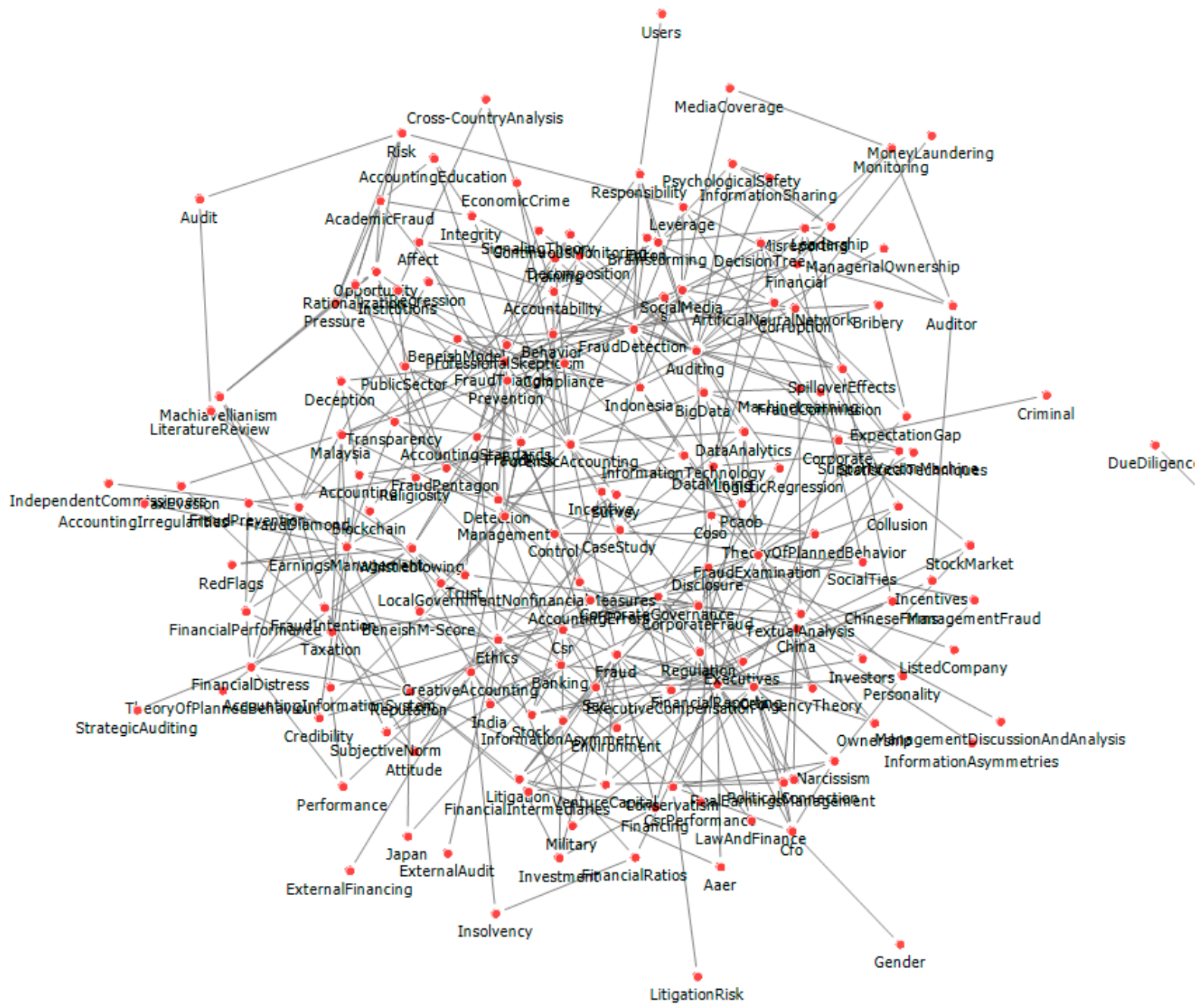

Figure 5. Keyword network (papers published 2015-2020).

Table 6. Keyword frequency from 2015 to 2020.

\begin{tabular}{cc}
\hline Keyword & Degree \\
\hline Auditing & 87 \\
Financial Reporting & 77 \\
Corporate Governance & 69 \\
Fraud Examination & 31 \\
Forensic Accounting & 27 \\
Ethics & 22 \\
Fraud Risk & 19 \\
Regulation & 18 \\
Fraud Triangle & 18 \\
Fraud Detection & 18 \\
Whistleblowing & 16 \\
China & 14 \\
Fraud & 13 \\
Disclosure & 13 \\
CEO & 12 \\
Corruption & 10 \\
CSR & 10 \\
CFO & 10 \\
Earnings Management & 10 \\
\hline
\end{tabular}


Table 6. Cont.

\begin{tabular}{cc}
\hline Keyword & Degree \\
\hline Fraud Diamond & 8 \\
Reputation & 8 \\
Corporate Fraud & 7 \\
Litigation & 7 \\
Malaysia & 7 \\
Data Mining & 7 \\
Executive Compensation & 7 \\
Management Fraud & 6 \\
Brainstorming & 6 \\
Accounting & 6 \\
Corporate & 6 \\
Rationalization & 6 \\
Nonfinancial Measures & 5 \\
Textual Analysis & 5 \\
Stock Market & 5 \\
Accountability & 5 \\
AAER & 5 \\
Detection & 5 \\
Banking & 5 \\
Machine Learning & 5 \\
Pressure & 5 \\
Opportunity & 5 \\
Investors & 4 \\
COSO & 4 \\
Fraud Pentagon & 4 \\
Big Data & 4 \\
\hline
\end{tabular}

Tables 7 and 8 show the results for degree centrality and betweenness centrality from 2015 to 2020, respectively. Notably, prior to 2015, "Auditing", "Fraud examination", "Corporate governance", and others were dominant; however, since 2015, although they were still highly ranked, fraud detection and its related techniques became more popular.

Table 7. Results of degree centrality (papers published 2015-2020).

\begin{tabular}{cc}
\hline Keyword & Degree Centrality \\
\hline Fraud Detection & 0.117647 \\
Fraud Triangle & 0.111765 \\
Auditing & 0.111765 \\
Financial Reporting & 0.111765 \\
Fraud Examination & 0.105882 \\
Ethics & 0.094118 \\
Corporate Governance & 0.088235 \\
Forensic Accounting & 0.088235 \\
Fraud Risk & 0.088235 \\
Fraud & 0.082353 \\
CEO & 0.082353 \\
China & 0.082353 \\
Regulation & 0.070588 \\
Earnings Management & 0.064706 \\
Fraud Diamond & 0.058824 \\
Whistleblowing & 0.058824 \\
Reputation & 0.058824 \\
Corporate Fraud & 0.052941 \\
Social Media & 0.052941 \\
CSR & 0.052941 \\
Executive Compensation & 0.052941 \\
\hline
\end{tabular}


Table 8. Results of betweenness centrality (papers published 2015-2020).

\begin{tabular}{cc}
\hline Keyword & Node Betweenness Centrality \\
\hline Auditing & 0.120193 \\
Fraud Detection & 0.112247 \\
Fraud Triangle & 0.105529 \\
Financial Reporting & 0.103099 \\
Fraud Risk & 0.088452 \\
Ethics & 0.084771 \\
Fraud Examination & 0.076056 \\
Corporate Governance & 0.066882 \\
Forensic Accounting & 0.056379 \\
Fraud & 0.049984 \\
Whistleblowing & 0.049091 \\
Disclosure & 0.047249 \\
CEO & 0.044715 \\
Earnings Management & 0.043685 \\
China & 0.041523 \\
Regulation & 0.032303 \\
Fraud Diamond & 0.031661 \\
Reputation & 0.030496 \\
CSR & 0.029751 \\
Accounting Standards & 0.029249 \\
Social Media & 0.028958 \\
\hline
\end{tabular}

Table 9 reports the cluster analysis from 2015 to 2020. The studies in Cluster 1 mainly focus on how managers or auditors behave when there are red flags in financial reporting [70]. Cluster 2 focuses on finding whether firms with high corporate social responsibility are less likely to get involved in accounting fraud based on Chinese evidence [71]. Cluster 3 primarily consists of studies focused on executive compensation. The major keywords include financial reporting, executive compensation, agency costs, CEO, and information asymmetry. Related studies implicitly assume that a CEO's excessive equity-based compensation above optimal levels may lead to the manipulation of financial statements to enhance stock prices because equity compensation, in particular, is directly linked to prices, while the CEO's incentive and actions are hidden from external stakeholders. Burns and Kedia [19] found that some CEO compensation packages were significantly associated with the restatement of financial statements, in violation of the US Generally Accepted Accounting Principles. Specifically, financial restatement increases CEO stock option sensitivity, thus providing incentives by increasing stock prices [72], because the convexity of stock options can limit the CEO's cost of misreporting. Efendi et al. [20] documented that firms with profitable option holdings of the CEO that are financially constrained by the interest-coverage debt covenant are raising new debt or equity capital and having the CEO as a chairperson on the board indicates a high propensity toward financial misstatements. Finally, Armstrong et al. [22] examined two types of equity incentives: Delta (stock and stock option sensitivity to stock prices) and Vega (stock and stock option sensitivity to stock return volatility), as well as financial misreporting. They found that the Vega incentive is more significantly and positively associated with financial misreporting than the Delta, while results on the Delta incentive are somewhat mixed. Cluster 4 focuses on reduction in fraud risk. Particularly, Brazel et al. [73] suggest that high inconsistency between revenues and revenue-related non-financial measures refer to red flags. Firms with an audit committee that has industry expertise or more tenure can mitigate those red flags. In Cluster 5, Gepp et al. [74] argue that auditing should pay close attention to big data techniques to detect frauds. Fay and Negangard [75] show experimental practices using big data technique. In Cluster 6, many fraud theories were evolved from the fraud triangle theory; that is, a person can commit the fraud due to the fact of three factors: rationalization, opportunity, and pressure. For instance, the fraud pentagon adds competence and arrogance to the existing theory [76], and the fraud diamond adds capability to the existing theory [77]. 
Table 9. Cluster analysis (papers published 2015-2020).

\begin{tabular}{|c|c|c|}
\hline Cluster & Topics & Analysis \\
\hline Cluster 1 & Ethics, red flags, fraud prevention, transparency & $\begin{array}{c}\text { Cluster } 1 \text { centers on the effect of red flags on financial } \\
\text { reporting and auditors or managers behavior. }\end{array}$ \\
\hline Cluster 2 & CSR, reputation, disclosure, accounting irregularities & $\begin{array}{l}\text { Cluster } 2 \text { focuses on corporate social responsibility and } \\
\text { accounting fraud. }\end{array}$ \\
\hline Cluster 3 & $\begin{array}{l}\text { Executive compensation, information asymmetry, } \\
\text { CEO, CFO, agency theory }\end{array}$ & $\begin{array}{l}\text { Cluster } 3 \text { centers on executive compensation. This line } \\
\text { of research explores the effect of top executives' } \\
\text { compensation packages on financial statement fraud to } \\
\text { divert their personal benefits [19]. }\end{array}$ \\
\hline Cluster 4 & $\begin{array}{l}\text { Auditing, nonfinancial measures, brainstorming, } \\
\text { fraud risk }\end{array}$ & $\begin{array}{l}\text { Cluster } 4 \text { focuses on efforts on reducing fraud risk } \\
\text { by auditors. }\end{array}$ \\
\hline Cluster 5 & $\begin{array}{l}\text { Forensic accounting, fraud detection, machine } \\
\text { learning, data mining, data analytics, big data, } \\
\text { artificial neural network. }\end{array}$ & $\begin{array}{c}\text { Cluster } 5 \text { centers on detecting accounting fraud using } \\
\text { various techniques. }\end{array}$ \\
\hline Cluster 6 & Fraud diamond, fraud triangle, fraud pentagon & $\begin{array}{l}\text { In Cluster } 6 \text {, in addition to the fraud triangle, } \\
\text { researchers approach various fraud models. }\end{array}$ \\
\hline
\end{tabular}

In sum, there was a change in the topics of the papers from 2015 to 2020 compared to those from 2002 to 2014, with extensive interest in fraud detection techniques, such as big data, while some topics, such as executive compensation [19-21] and corporate social responsibility [28], continue being examined.

\subsection{Authorship Analysis}

Between 2002 and 2020, 1096 researchers authored 932 papers that we used in the analysis as follows. First, we constructed a two-mode network composed of papers and authors. Researchers with more than two published papers were selected for the analysis. Table 10 shows the number of publications per author. Carpenter, Zimbelman, Jones, Kaplan, Pamungkas, and Rezaee conducted multiple accounting fraud studies. To construct the one-mode network, we established links between authors and one or more coauthors. The one-mode network of the authors is illustrated in Figure 6. The conversion was performed based on the inner product algorithm. The one mode network author network allowed us to analyze the co-authorship network and clusters of researchers on accounting fraud research topics. The value of the inner product was calculated on the basis of the number of coauthored research papers between two researchers:

$$
\text { Inner Product }=\sum_{k=1}^{n} C_{i k} C_{j k}
$$

where $C j k$ is whether author $j$ appeared in article $k$.

We measured degree centrality and betweenness centrality to analyze author influence. Degree centrality captures the leading scholars in fraud research. According to the results reported in Table 11, Jones, Carpenter, Brazel, and Cohen stand out. Their studies are related to auditors' fraud judgments, risk assessment, and brainstorming.

Betweenness centrality captures the authors who bridge other authors, meaning that authors with a high level of betweenness centrality can be highly influential in extending the various subtopics in fraud research. The results are presented in Table 12, with Carpenter, Brazel, Jones, Zimbelman, and Riley ranking the highest. Notably, Riley is a new author, while Brazel, Carpenter, and Jones ranked high in terms of both degree centrality and betweenness centrality. 


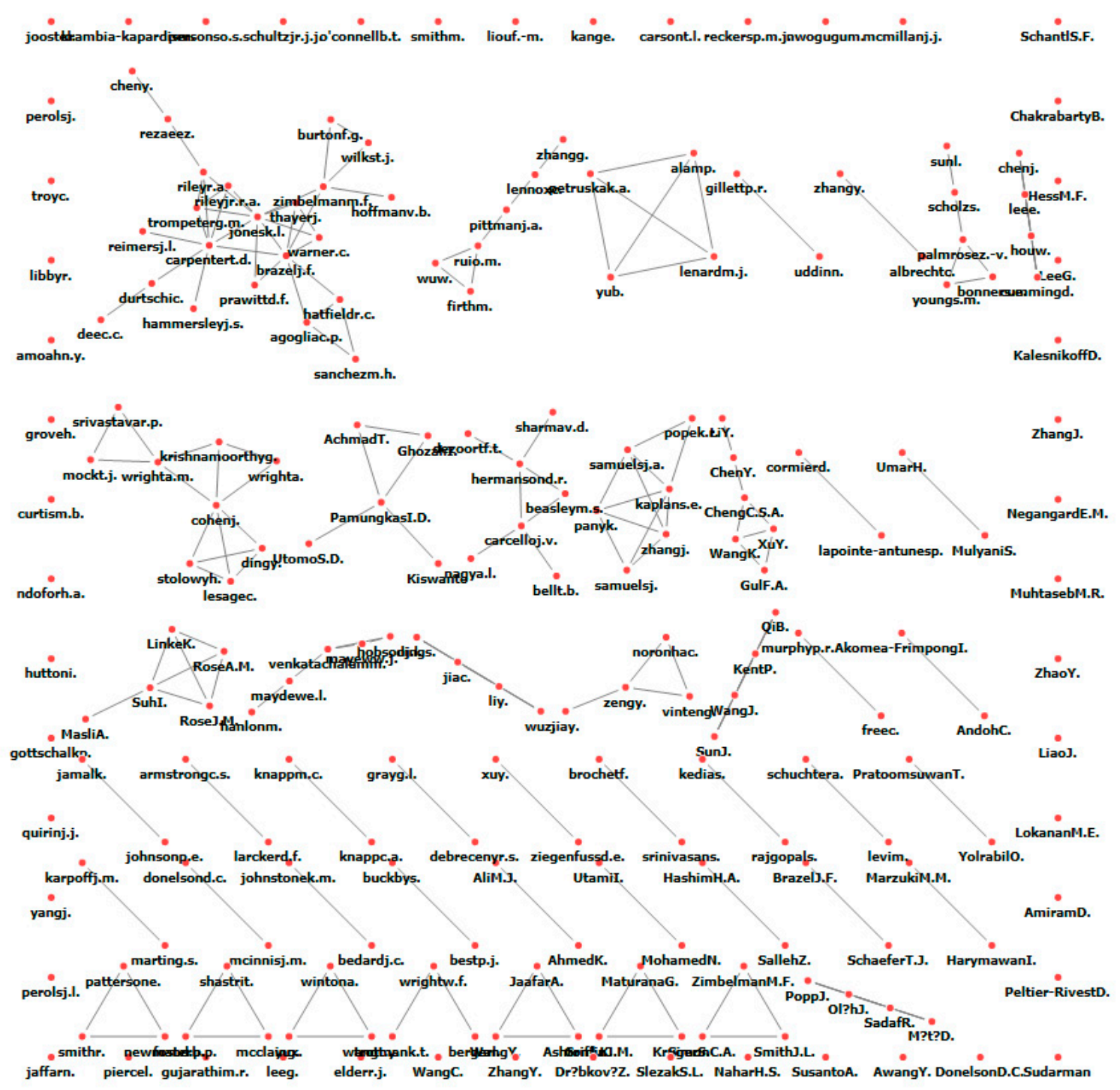

Figure 6. Author network.

Table 10. Articles per author.

\begin{tabular}{cc}
\hline Author Node & Degree \\
\hline Carpenter, T.D. & 7 \\
Zimbelman, M.F. & 6 \\
Kaplan, S.E. & 6 \\
Jones, K.L. & 6 \\
Pamungkas, l.D. & 6 \\
Hui, K.W. & 5 \\
Cumming, D. & 5 \\
Cohen, J. & 5 \\
Carcello, J.V. & 4 \\
Lennox, C. & 4 \\
Albrecht, C. & 4 \\
Lee, E. & 4 \\
Venkatachalam, M. & 4 \\
Suh, I.S. & 4 \\
Ghozali, I. & 4 \\
\hline
\end{tabular}


Table 11. Results of degree centrality (author network).

\begin{tabular}{cc}
\hline Author Node & Degree Centrality \\
\hline Jones, K.L. & 0.041096 \\
Carpenter, T.D. & 0.03653 \\
Brazel, J.F. & 0.03653 \\
Cohen, J. & 0.027397 \\
Zimbelman, M.F. & 0.022831 \\
Kaplan, S.E. & 0.022831 \\
Carcello, J.V. & 0.018265 \\
Zhang, J. & 0.018265 \\
Pany, K. & 0.018265 \\
Riley, R.A. & 0.018265 \\
Trompeter, G.M. & 0.018265 \\
Samuels, J.A. & 0.018265 \\
Wright, A.M. & 0.018265 \\
Hermanson, D.R. & 0.018265 \\
Pamungkas, I.D. & 0.018265 \\
Suh, I.S. & 0.018265 \\
\hline
\end{tabular}

Table 12. Results of betweenness centrality (author network).

\begin{tabular}{cc}
\hline Author Node & Node Betweenness Centrality \\
\hline Carpenter, T.D. & 0.003519 \\
Brazel, J.F. & 0.003289 \\
Jones, K.L. & 0.002953 \\
Zimbelman, M.F. & 0.002346 \\
Riley, R.A. & 0.001592 \\
Durtschi, C. & 0.000838 \\
Rezaee, Z. & 0.000838 \\
Cohen, J. & 0.000691 \\
Wright, A.M. & 0.000503 \\
Hatfield, R.C. & 0.000398 \\
Agoglia, C.P. & 0.000398 \\
Carcello, J.V. & 0.000377 \\
Hermanson, D.R. & 0.000377 \\
Rui, O.M. & 0.000251 \\
Pittman, J.A. & 0.000251 \\
Cheng, C.S.A. & 0.000251 \\
Pamungkas, I.D. & 0.000209 \\
Palmrose, Z.V. & 0.000168 \\
Lennox, C. & 0.000168 \\
Venkatachalam, M. & 0.000168 \\
Chen, Y. & 0.000168 \\
\hline
\end{tabular}

Clustering analysis was conducted to identify the research groups, and the results are presented in Table 13. In Cluster 1, Carpenter, Trumpeter, Riley, Hammersley, and Reimers are key authors that published studies in collaboration with other authors. Carpenter focused on fraud risk and judgment and assessment during the audit process, co-authoring studies with Brazel, Reimers, Durtschi, among others [18,78-80]. Carpenter, Jones, Riley, and Trompeter co-authored two review studies on fraud literature [3,81], while other authors examined various subtopics related to auditing. Hammersley, Bamber, and Carpenter collaborated on fraud risk documentation during audit planning, which affects external auditors' evidence evaluation and fraud risk assessments [82]. 
Table 13. Results of clustering analysis.

\begin{tabular}{|c|c|c|}
\hline Cluster & Authors & Description \\
\hline Cluster 1 & $\begin{array}{c}\text { Carpenter, Trumpeter, Riley, Hammersley, } \\
\text { and Reimers }\end{array}$ & $\begin{array}{l}\text { Carpenter is a key author in Cluster } 1 \text {. This author and } \\
\text { others published several papers related to auditing, external } \\
\text { auditors' fraud assessment, professional skepticism [78,82], } \\
\text { and review papers about audit research [81]. }\end{array}$ \\
\hline Cluster 2 & Suh, Linke, Rose, and Masli & $\begin{array}{l}\text { Key authors in Cluster } 2 \text { are represented by Suh, Linke, } \\
\text { Rose, and Masli. These authors studied top executives' } \\
\text { misreporting behavior and characteristics. }\end{array}$ \\
\hline Cluster 3 & Cohen, Ding, Lesage, Srivastava, and Stolowy & $\begin{array}{c}\text { Cohen in Cluster } 3 \text { focused on studies on the role of } \\
\text { corporate governance based on top management by } \\
\text { analyzing media. }\end{array}$ \\
\hline Cluster 4 & Hobson, Mayew, and Venkachalam & $\begin{array}{l}\text { Centered on Mayew, the authors in Cluster } 4 \text { co-authored } \\
\text { and published fraud studies in a detection on } \\
\text { financial misreporting. }\end{array}$ \\
\hline Cluster 5 & Carcello, Beasley, Hermanson, and Nagy & $\begin{array}{l}\text { In Cluster 5, Carcello is a key author who explored the } \\
\text { effects of audit tenure and specialization, and client } \\
\text { characteristics such as the extent of the likelihood of } \\
\text { accounting fraud }[16,45] .\end{array}$ \\
\hline Cluster 6 & Kaplan, Samuels, Zhang, Pope, and Pany & $\begin{array}{l}\text { Centered on Kaplan, the contributing article in Cluster } 6 \\
\text { mainly examined fraud intentions such as fraudsters' } \\
\text { gender, auditor type, and whistleblowing [83-86]. }\end{array}$ \\
\hline Cluster 7 & Lennox, Hui, Zhang, and Pittman & $\begin{array}{l}\text { Lennox in Cluster } 7 \text { is a key author and examined the effect } \\
\text { of the Big Five auditors on the likelihood of accounting } \\
\text { fraud [87], tax aggressiveness [88], and fraud consequences } \\
\text { such as lawsuits against auditors and market valuation in } \\
\text { relation to fraud }[89,90] \text {. }\end{array}$ \\
\hline
\end{tabular}

Cluster 2 centers on Suh, Linke, Rose, and Masli. These authors focused on the various attributes of top executives' (C-suites) misreporting behavior. Norman et al. [91] suggested that the role of internal audit committee expertise may not necessarily mitigate internal auditors' compromise on financial misstatements based on the experiment of chief audit executives. Further, Suh, Sweeny, Linke, and Wall investigated the social and contextual attributes of 13 chief financial executives involved in accounting fraud cases using face-to-face interviews [92]. Their research aimed to analyze the risk factors of the fraud diamond model toward accounting fraud and corporate governance as a moderating variable in relation to the risk factors in the fraud diamond model toward accounting fraud. The study uses 12 fraud companies and 32 non-fraud companies listed by the Indonesian stock exchange that broke article VIII.G.7 issued by the Financial Services Authority. Using logistic regression, the research results show that only a change in direction significantly affects accounting fraud. Moreover, the board of commissioners, independent commissioners, and institutional ownership weaken the change relationship toward accounting fraud. This research suggests that investors should be more careful in investing. In particular, companies that carry out a higher change in direction tend to exhibit accounting fraud. Furthermore, the company can improve the board of commissioners, independent commissioners, and institutional ownership, so that the level of accounting fraud can be lowered.

Cluster 3 includes Cohen, Ding, Lesage, and Stolowy. Centered on Cohen, various authors examined manager behavior and disclosure by analyzing press articles. Cohen et al. [93] used press articles to analyze manager behavior and found that managers' personal traits were crucial for financial statement fraud. Subsequently, they documented that media bias and press articles can cause disparities between the perception of auditor duties of the public and practice [94]. 
Cluster 4 focuses on fraud detection in financial misreporting using speech and/or the linguistic tone. Key authors include Hobson, Mayew, and Venkachalam. Hobson et al. [95] documented that vocal emotion analysis (also known as vocal dissonance markers) indicates that $\mathrm{CEO}$ speech is significantly associated with financial restatements.

In Cluster 5, various authors-Beasley, Hermanson, and Nagy-co-authored studies with a key author, Carcello. Beasley, Carcello, Hermanson, and Lapides documented that fraudulent firms in the technology, healthcare, or financial services sectors have different characteristics of corporate governance compared to their counterparts, such as fewer independent audit committees and audit committee meetings and less independent boards [13]. Carcello and Nagy concentrated on auditing-related topics [16,45], especially audit firm tenure, auditor specialization, and fraudulent financial reporting. Mandatory audit firm rotation did not necessarily have positive effects on audit quality, since fraudulent firms perpetrate financial statements in the first three years of the contract between auditors and clients [16]. Client firm size can moderate the relationship between auditors' industry specialization and the fraud committed by the client firm [45].

Cluster 6 includes Kaplan, Samuels, Zhang, Pope, and Pany who focused on reporting intention. Kaplan, Pope, and Samuels determined that in an experimental setting, employees tend to report fraud predication to internal auditors rather than external auditors [83]. Kaplan, Pany, Samuels, and Zhang found that whistleblowing through anonymous and reporting channels is indifferent to that from non-anonymous reporting channels [84].

Finally, Cluster 7 includes Lennox, Hui, Zhang, and Pittman. Lennox, Hui, and Zhang documented that investors could assess the likelihood of fraud incidences, which, as a result, affects the market valuation of fraudulent firm earnings even before fraud is publicly announced [88]. Lennox et al. [86] found that tax-aggressive firms tend to commit less fraud. Overall, the authorship analysis suggests that the key contributors to the clusters are Carpenter, Jones, Brazel, Zimbelman, Cohen, Cumming, Carcello, Kaplan, and Lennox.

\section{Conclusions}

This study conducted network analysis to understand the research trends in the field of accounting fraud. The network analysis included 932 international studies by 1096 authors published between 2002 and 2020 and indexed on Scopus, a leading academic database, and identified the following trends in accounting fraud literature. Because business intelligence and data analytics have evolved significantly since 2015, we analyzed the keywords over two periods: 2014 and before and from 2015 to 2020. In accounting academia, the role of IT audits has been highly stressed in relation with big data and other business intelligence [96], while data mining and analytics have become been a must for audit firms [97].

The keyword analysis of the articles published in 2014 and before suggested that financial reporting, auditing, corporate governance, and fraud examination as well as other related subtopics were the most actively researched. Each topic included a major school of thought but was correlated with other topics as well. The big accounting scandals, such as Enron and WorldCom, and many fraud studies were published and auditing paid attention to identifying the roles of external auditors, their audit processes, risk assessment, and so forth. Many researchers have expanded on this topic by examining corporate governance relating to the SOX Act, including top executives, directors, and internal controls. The number of publications showed an increasing trend. Recent studies have extended these topics by examining the effect of accounting fraud on stakeholders such as legislators, shareholders, and employees.

Further, the keyword analysis from 2015 to 2020 was similar to the previous ones. This suggests that auditing, financial reporting, corporate governance, and fraud examinations have been constantly explored by researchers. Surprisingly, the results of degree centrality and betweenness centrality indicated that studies on fraud detection, the fraud triangle, and auditing were rigorously examined as information technology and data analytics relating to audit and accounting information systems (AIS) became vital. 
Overall, studies before 2015 actively explored the main schools of thoughts, such as auditing, corporate governance, and financial reporting, to identify the causes and consequences in detail. The most recent studies, since 2015, mainly focus on designing fraud detection and discussing fraud theory (e.g., fraud triangle). The scope of stakeholders is broadening from management and auditors to directors, policy makers, and employees as well.

The authorship analysis identified several highly influential authors and authors that were well connected to their co-authors to extend various subtopics in fraud research. In particular, the degree centrality analysis determined that Jones, Brazel, Carpenter, Cohen, Zimbelman, Kaplan, Carcello, and Zhang contributed to many fraud-related publications, implying that these authors are highly influential in the literature. The betweenness centrality showed similar results to those of degree centrality, given that these authors are connected to one another as a result of co-authorship. Their studies focused on auditing and identifying auditors' fraud judgments. We can imply from the results of the authorship analysis that those that coincided with those of the keyword analysis that auditing is highly placed as a hot topic in the literature, regardless of the sample period.

Accounting fraud can destroy companies and ruin employees and investors' lives, as evidenced by the Enron scandal. The more transactions companies record, the more complex the accounting system has to be to comply with the required standards. Despite its usefulness and convenience, a complicated system may result in more accounting errors and fraud. In this respect, it is extremely critical to proactively detect and systematically manage fraudulent accounting. Digital transformation has resulted in extensive changes in the accounting field. As such, fraudulent accounting has once again attracted the attention of scholars and managers. While the previous accounting fraud detection technologies could not comprehensively consider the various human behavioral factors and potential risks, emerging digital forensic technologies, such as big data analysis and artificial intelligence, play a critical role in preventing, detecting, and responding to accounting scandals based on the vast amounts of data they use. In this regard, both academia and practitioners have embraced new topics related to accounting fraud detection technologies such as artificial intelligence, big data, blockchain, and machine learning. In this regard, recent studies paid attention to these new technologies in fraud detection. Some researchers predicted the importance of big data and blockchain technology $[98,99]$. Big data can detect financial statement errors and/or fraud committed by organizations and auditors because artificial intelligence can discover fictitious operations faster than auditors, given that they manually review $10 \%$ of the expense reports at best [98]. Every transaction can be saved as block transactions only when authenticity is confirmed by users through cryptography, a chain of digital signatures, mitigating errors, or artificial transactions [99]. Also, recent research has focused on devising a novel model for fraud detection by applying machine learning. For example, Bao et al. [100] introduced a new fraud prediction model using machine learning, whereas existing studies used logistic regression models based on financial ratios. Brown et al. [101] also applied machine learning to capture the relevant topics of financial statements to detect accounting fraud. As research on accounting fraud using artificial intelligence is rather limited, researchers are increasingly using machine learning to detect financial statement fraud and demonstrating that their approaches are more robust than logistic regression models. We expect that more research is required in this area, given the emergence of the Fourth Industrial Revolution.

This study contributed to the literature by identifying the research trends in accounting fraud using network analysis as opposed to traditional review papers. There was a dramatic increase in the number of research projects investigating accounting fraud detection and prevention over the 30 years. However, there has not been sufficient research to integrate theories and practices. Even though meaningful research efforts have tempted to synthesize information various fraudulent accounting studies using text analysis, a comprehensive view of accounting fraud theories has yet to be provided. This research identified key research areas and groups based on 932 articles published in highly ranked accounting 
journals. Specifically, we used networks of authors as well as keywords to determine the current research trends, while traditional review papers used meta-analysis, among other methods. We expected that the findings will allow researchers to expand the scope of research to a wide range of subfields in accounting fraud research in the future.

The limitations of this study are as follows. First, this study only analyzed papers retrieved from the Scopus database; as such, influential articles not indexed on Scopus may have been omitted from the analysis. Moreover, this study may not have included all journals indexed in Scopus for all years. Scopus has very limited electronic version articles published before 1980. Pre-1980 articles may have been omitted. The addition of prestigious databases, such as Web of Science, can enrich the research to explore specific patterns of research productivity and authorship. Second, it is necessary to form networks of researchers, citation relationships, and concurrent citations, as well as keywords and authors for a diversified analysis of research trends. While this study has only analyzed keywords and author networks to identify research trends, future research should construct various other networks to understand the research trends in the field of accounting fraud to provide valuable implications for researchers. Third, from a perspective of sustainable accounting, the scope of our study was limited to corporate social responsibility, business ethics, corporate culture, and accountability [57,58,102-105], because topics, such as social and/or environmental accounting, linked to accounting fraud are scarce. Future research may explore the relationship between social and/or environmental reporting disclosure and the likelihood of accounting fraud. Finally, a sample period from 2002 to 2020 might lead to biased implications, as major accounting scandals occurred in the 2000s. The sample period prior to the 2000s might add different insights to our study.

Author Contributions: Conceptualization, S.-J.Y. and J.-S.R.; methodology, S.-J.Y. and J.-S.R.; software, J.-S.R.; validation, S.-J.Y. and J.-S.R.; formal analysis, S.-J.Y. and J.-S.R. All authors have read and agreed to the published version of the manuscript.

Funding: This research received no external funding.

Institutional Review Board Statement: Not applicable.

Informed Consent Statement: Not applicable.

Data Availability Statement: Not applicable.

Acknowledgments: Thank you to the anonymous peer reviewers and the editors for their critical comments, which helped to improve significantly the quality of this paper.

Conflicts of Interest: The authors declare no conflict of interest.

\section{References}

1. Lamberton, G. Sustainability accounting-A brief history and conceptual framework. Account. Forum 2005, 29, 7-26. [CrossRef]

2. Hogan, C.E.; Rezaee, Z.; Riley, R.A., Jr.; Velury, U.K. Financial statement fraud: Insights from the academic literature. Audit. J. Pract. Theory 2008, 27, 231-252. [CrossRef]

3. Trompeter, G.M.; Carpenter, T.D.; Desai, N.; Jones, K.L.; Riley, R.A., Jr. A synthesis of fraud-related research. Audit. J. Pract. Theory 2013, 32, 287-321. [CrossRef]

4. Amiram, D.; Bozanic, Z.; Cox, J.D.; Dupont, Q.; Karpoff, J.M.; Sloan, R. Financial reporting fraud and other forms of misconduct: A multidisciplinary review of the literature. Rev. Account. Stud. 2018, 23, 732-783. [CrossRef]

5. Uysal, Ö.Ö. Business ethics research with an accounting focus: A bibliometric analysis from 1988 to 2007. J. Bus. Ethics 2010, 93, 137-160. [CrossRef]

6. Kılıç, M.; Uyar, A.; Koseoglu, M.A. Co-authorship network analysis in the accounting discipline. Aust. Account. Rev. 2019, 29, 235-251.

7. Wakefield, R. Networks of Accounting Research: A Citation-Based Structural and Network Analysis. Br. Account. Rev. 2008, 40, 228-244. [CrossRef]

8. Lee, S.M.; Rha, J.S. A Network Text Analysis of Published Papers in Service Business, 2007-2017: Research Trends in the Service Sector. Serv. Bus. 2018, 12, 809-831. [CrossRef]

9. Dechow, P.M.; Sloan, R.G.; Sweeney, A.P. Causes and consequences of earnings manipulation: An analysis of firms subject to enforcement actions by the SEC. Contemp. Account. Res. 1996, 13, 1-36. [CrossRef]

10. Gerety, M.; Lehn, K. The causes and consequences of accounting fraud. Manag. Decis. Econ. 1997, 18, 587-599. [CrossRef] 
11. Giroux, G. What went wrong? Accounting fraud and lessons from the recent scandals. Soc. Res. 2008, 75, 1205-1238.

12. Beasley, M.S. An empirical analysis of the relation between the board of director composition and financial statement fraud. Account. Rev. 1996, 71, 443-465.

13. Beasley, M.S.; Carcello, J.V.; Hermanson, D.R.; Lapides, P.D. Fraudulent financial reporting: Consideration of industry traits and corporate governance mechanisms. Account. Horiz. 2000, 14, 441-454. [CrossRef]

14. Cohen, J.; Krishnamoorthy, G.; Wright, A.M. Corporate governance and the audit process. Contemp. Account. Res. 2002, 19, 573-594. [CrossRef]

15. Abbott, L.J.; Park, Y.; Parker, S. The effects of audit committee activity and independence on corporate fraud. Manag. Financ. 2000, 26, 55-68. [CrossRef]

16. Carcello, J.V.; Nagy, A.L. Audit firm tenure and fraudulent financial reporting. Audit. J. Pract. Theory 2004, 23, 55-69. [CrossRef]

17. Hoffman, V.B.; Zimbelman, M.F. How strategic reasoning and brainstorming can help auditors detect fraud. Curr. Issues Audit. 2012, 6, 25-33. [CrossRef]

18. Brazel, J.F.; Jones, K.L.; Zimbelman, M.F. Using nonfinancial measures to assess fraud risk. J. Account. Res. 2009, 47, 1135-1166. [CrossRef]

19. Burns, N.; Kedia, S. The impact of performance-based compensation on misreporting. J. Financ. Econ. 2006, 79, 35-67. [CrossRef]

20. Efendi, J.; Srivastava, A.; Swanson, E.P. Why do corporate managers misstate financial statements? The role of option compensation and other factors. J. Financ. Econ. 2007, 85, 667-708. [CrossRef]

21. Erickson, M.; Hanlon, M.; Maydew, E.L. Is there a link between executive equity incentives and accounting fraud? J. Account. Res. 2006, 44, 113-143. [CrossRef]

22. Armstrong, C.S.; Jagolinzer, A.D.; Larcker, D.F. Chief executive officer equity incentives and accounting irregularities. J. Account. Res. 2010, 48, 225-271. [CrossRef]

23. Farber, D.B. Restoring trust after fraud: Does corporate governance matter? Account. Rev. 2005, 80, 539-561. [CrossRef]

24. Graham, J.R.; Li, S.; Qiu, J. Corporate misreporting and bank loan contracting. J. Financ. Econ. 2008, 89, 44-61. [CrossRef]

25. Karpoff, J.M.; Lee, D.S.; Martin, G.S. The consequences to managers for financial misrepresentation. In Accounting and Regulation; Di Pietra, R., McLeay, S., Ronen, J., Eds.; Springer: New York, NY, USA, 2014; pp. 339-375.

26. Fich, E.M.; Shivdasani, A. Financial fraud, director reputation, and shareholder wealth. J. Financ. Econ. 2007, 86, 306-336. [CrossRef]

27. Palmrose, Z.V.; Scholz, S. The circumstances and legal consequences of non-GAAP reporting: Evidence from restatements. Contemp. Account. Res. 2004, 21, 139-180. [CrossRef]

28. Kim, Y.; Park, M.S.; Wier, B. Is earnings quality associated with corporate social responsibility? Account. Rev. 2012, 87, 761-796. [CrossRef]

29. McNichols, M.F.; Stubben, S.R. Does earnings management affect firms' investment decisions? Account. Rev. 2008, 83, 1571-1603. [CrossRef]

30. Miller, G.S. The press as a watchdog for accounting fraud. J. Account. Res. 2006, 44, 1001-1033. [CrossRef]

31. Schrand, C.M.; Zechman, S.L. Executive overconfidence and the slippery slope to financial misreporting. J. Account. Econ. 2012, 53, 311-329. [CrossRef]

32. Sharma, A.; Panigrahi, P.K. A Review of Financial Accounting Fraud Detection Based on Data Mining Techniques. arXiv 2013, arXiv:1309.3944. [CrossRef]

33. Wang, S. A Comprehensive Survey of Data Mining-Based Accounting-Fraud Detection Research. In Proceedings of the 2010 International Conference on Intelligent Computation Technology and Automation, Changsha, China, 11-12 May 2010; pp. 50-53.

34. Montesdeoca, M.R.; Medina, A.J.S.; Santana, F.B. Research Topics in Accounting Fraud in the 21st Century: A State of the Art. Sustainability 2019, 11, 1570. [CrossRef]

35. Omair, B.; Alturki, A. A Systematic Literature Review of Fraud Detection Metrics in Business Processes. IEEE Access 2020, 8 , 26893-26903. [CrossRef]

36. Karpoff, J.M.; Koester, A.; Lee, D.S.; Martin, G.S. Proxies and databases in financial misconduct research. Account. Rev. 2017, 92, 129-163.

37. Donelson, D.C.; Kartapanis, A.; McInnis, J.M.; Yust, C.G. Measuring Accounting Fraud and Irregularities Using Public and Private Enforcement. Account. Rev. Forthcoming. Available online: https://doi.org/10.2308/TAR-2018-0592 (accessed on 1 April 2021).

38. Worrell, J.; Wasko, M.; Johnston, A. Social Network Analysis in Accounting Information Systems Research. Int. J. Account. Inf. Syst. 2013, 14, 127-137. [CrossRef]

39. Euske, K.J.; Hesford, J.W.; Malina, M.A. A Social Network Analysis of the Literature on Management Control. Manag. Account. Res. 2011, 23, 259-283. [CrossRef]

40. Fahimnia, B.; Tang, C.S.; Davarzani, H.; Sarkis, J. Quantitative Models for Managing Supply Chain Risks: A Review. Eur. J. Oper. Res. 2015, 247, 1-15. [CrossRef]

41. Fahimnia, B.; Sarkis, J.; Davarzani, H. Green Supply Chain Management: A Review and Bibliometric Analysis. Int. J. Prod. Econ. 2015, 162, 101-114. [CrossRef]

42. Rha, J.S. Trends of Research on Supply Chain Resilience: A Systematic Review using Network Analysis. Sustainability 2020, 12, 4343. [CrossRef] 
43. Church, B.K.; McMillan, J.J.; Schneider, A. Factors affecting internal auditors' consideration of fraudulent financial reporting during analytical procedures. Audit. J. Pract. Theory 2001, 20, 65-80. [CrossRef]

44. Saksena, P. The relationship between environmental factors and management fraud: An empirical analysis. Int. J. Commer. Bus. Manag. 2001, 11, 120. [CrossRef]

45. Carcello, J.V.; Nagy, A.L. Client size, auditor specialization and fraudulent financial reporting. Manag. Audit. J. 2004, 19, 651-668. [CrossRef]

46. Rezaee, Z.; Olibe, K.O.; Minmier, G. Improving corporate governance: The role of audit committee disclosures. Manag. Audit. J. 2003, 18, 530-537. [CrossRef]

47. Makkawi, B.; Schick, A. Are auditors sensitive enough to fraud? Manag. Audit. J. 2003, 18, 581-598. [CrossRef]

48. James, K.L. The effects of internal audit structure on perceived financial statement fraud prevention. Account. Horiz. 2003, 17, 315-327. [CrossRef]

49. Uzun, H.; Szewczyk, S.H.; Varma, R. Board composition and corporate fraud. Financ. Anal. J. 2004, 60, 33-43. [CrossRef]

50. Griffin, P.A.; Grundfest, J.A.; Perino, M.A. Stock price response to news of securities fraud litigation: An analysis of sequential and conditional information. Abacus 2004, 40, 21-48. [CrossRef]

51. Bedard, J.C.; Johnstone, K.M. Earnings manipulation risk, corporate governance risk, and auditors' planning and pricing decisions. Account. Rev. 2004, 79, 277-304. [CrossRef]

52. Rezaee, Z. Causes, consequences, and deterrence of financial statement fraud. Crit. Perspect. Account. 2005, 16, 277-298. [CrossRef]

53. Geiger, M.A.; North, D.S. Does hiring a new CFO change things? An investigation of changes in discretionary accruals. Account. Rev. 2006, 81, 781-809. [CrossRef]

54. Dyck, A.; Morse, A.; Zingales, L. Who blows the whistle on corporate fraud? J. Financ. 2010, 65, 2213-2253. [CrossRef]

55. Rodgers, W.; Söderbom, A.; Guiral, A. Corporate social responsibility enhanced control systems reducing the likelihood of fraud. J. Bus. Ethics 2015, 131, 871-882. [CrossRef]

56. Cumming, D.; Hou, W.; Lee, E. Business ethics and finance in greater China: Synthesis and future directions in sustainability, CSR, and fraud. J. Bus. Ethics 2016, 138, 601-626. [CrossRef]

57. Harjoto, M.A. Corporate social responsibility and corporate fraud. Soc. Responsib. J. 2017, 13, 762-779. [CrossRef]

58. LópezPuertas-Lamy, M.; Desender, K.; Epure, M. Corporate social responsibility and the assessment by auditors of the risk of material misstatement. J. Bus. Finan. Account. 2017, 44, 1276-1314. [CrossRef]

59. Prasad, A.; Green, P. Organizational competencies and dynamic accounting information system capability: Impact on AIS processes and firm performance. J. Inf. Syst. 2015, 29, 123-149. [CrossRef]

60. Cram, W.A.; Gallupe, R.B. A method to evaluate information systems control alignment. J. Inf. Syst. 2016, 30, 117-135. [CrossRef]

61. Kamada, T.; Kawai, S. An Algorithm for Drawing General Undirected Graphs. Inf. Process. Lett. 1989, 31, 7-15. [CrossRef]

62. Ravisankar, P.; Ravi, V.; Rao, G.R.; Bose, I. Detection of financial statement fraud and feature selection using data mining techniques. Decis. Support Syst. 2011, 50, 491-500. [CrossRef]

63. Green, B.P.; Choi, J.H. Assessing the risk of management fraud through neural network technology. Auditing 1997, 16, 14-28.

64. Rijsenbilt, A.; Commandeur, H. Narcissus enters the courtroom: CEO narcissism and fraud. J. Bus. Ethics 2013, 117, 413-429. [CrossRef]

65. Blondel, V.D.; Guillaume, J.L.; Lambiotte, R.; Lefebvre, E. Fast unfolding of communities in large networks. J. Stat. Mech. Theory Exp. 2008, 2008, 10008. [CrossRef]

66. Dechow, P.M.; Ge, W.; Larson, C.R.; Sloan, R.G. Predicting material accounting misstatements. Contemp. Account. Res. 2011, 28, 17-82. [CrossRef]

67. Lin, J.W.; Hwang, M.I.; Becker, J.D. A fuzzy neural network for assessing the risk of fraudulent financial reporting. Manag. Audit. J. 2003, 18, 657-665. [CrossRef]

68. Abbasi, A.; Albrecht, C.; Vance, A.; Hansen, J. Metafraud: S meta-learning framework for detecting financial fraud. MIS Quart. 2012, 36, 1293-1327. [CrossRef]

69. Chiu, P.C.; Teoh, S.H.; Tian, F. Board interlocks and earnings management contagion. Account. Rev. 2013, 88, 915-944. [CrossRef]

70. Brazel, J.F.; Lucianetti, L.; Schaefer, T.J. Reporting concerns about earnings quality: An examination of corporate managers. J. Bus. Ethics 2020, 1-23. [CrossRef]

71. Liao, L.; Chen, G.; Zheng, D. Corporate social responsibility and financial fraud: Evidence from China. Account. Financ. 2019, 59, 3133-3169. [CrossRef]

72. Billings, B.A.; Gao, X.; Jia, Y. CEO and CFO equity incentives and the pricing of audit services. Audit. J. Pract. Theory 2014, 33, 1-25. [CrossRef]

73. Brazel, J.F.; Schmidt, J.J. Do auditors and audit committees lower fraud risk by constraining inconsistencies between financial and nonfinancial measures? Audit. J. Pract. Theory 2019, 38, 103-122. [CrossRef]

74. Gepp, A.; Linnenluecke, M.K.; O'Neill, T.J.; Smith, T. Big data techniques in auditing research and practice: Current trends and future opportunities. J. Account. Lit. 2018, 40, 102-115. [CrossRef]

75. Fay, R.; Negangard, E.M. Manual journal entry testing: Data analytics and the risk of fraud. J. Account. Educ. 2017, 38, 37-49. [CrossRef]

76. Yulianti, S.R.P.; Widowati, Y.S.; Prapti, L. Influence of fraud pentagon toward fraudulent financial reporting in Indonesia an empirical study on financial sector listed in Indonesian stock exchange. Int. J. Sci. Technol. Res. 2019, 8, $237-242$. 
77. Sabrun, I.M.; Muhamad, R.; Yusoff, H.; Darus, F. Do Shariah-compliant companies engage lesser earnings management behaviour? Asian J. Bus. Account. 2018, 11, 1-36. [CrossRef]

78. Hui, K.W.; Lennox, C.; Zhang, G. The market's valuation of fraudulently reported earnings. J. Bus. Financ. Account. 2014, 41, 627-651. [CrossRef]

79. Carpenter, T.D.; Durtschi, C.; Gaynor, L.M. The incremental benefits of a forensic accounting course on skepticism and fraudrelated judgments. Issue Account. Educ. 2011, 26, 1-21. [CrossRef]

80. Carpenter, T.D.; Reimers, J.L. Professional skepticism: The effects of a partner's influence and the level of fraud indicators on auditors' fraud judgments and actions. Behav. Res. Account. 2013, 25, 45-69. [CrossRef]

81. Trompeter, G.M.; Carpenter, T.D.; Jones, K.L.; Riley, R.A., Jr. Insights for research and practice: What we learn about fraud from other disciplines. Account. Horiz. 2014, 28, 769-804. [CrossRef]

82. Hammersley, J.S.; Bamber, E.M.; Carpenter, T.D. The influence of documentation specificity and priming on auditors' fraud risk assessments and evidence evaluation decisions. Account. Rev. 2010, 85, 547-571. [CrossRef]

83. Kaplan, S.E.; Pany, K.; Samuels, J.A.; Zhang, J. An examination of the effects of procedural safeguards on intentions to anonymously report fraud. Audit. J. Pract. Theory 2009, 28, 273-288. [CrossRef]

84. Kaplan, S.E.; Pany, K.; Samuels, J.; Zhang, J. An examination of the association between gender and reporting intentions for fraudulent financial reporting. J. Bus. Ethics 2009, 87, 15-30. [CrossRef]

85. Kaplan, S.E.; Pope, K.R.; Samuels, J.A. An examination of the effect of inquiry and auditor type on reporting intentions for fraud. Audit. J. Pract. Theory 2011, 30, 29-49. [CrossRef]

86. Kaplan, S.E.; Pany, K.; Samuels, J.; Zhang, J. An examination of anonymous and non-anonymous fraud reporting channels. Adv. Account. 2012, 28, 88-95. [CrossRef]

87. Lennox, C.S.; Pittman, J. Big Five Audits and Accounting Fraud . Unpublished.

88. Lennox, C.; Lisowsky, P.; Pittman, J. Tax aggressiveness and accounting fraud. J. Account. Res. 2013, 51, 739-778. [CrossRef]

89. Lennox, C.; Li, B. Accounting misstatements following lawsuits against auditors. J. Account. Econ. 2014, 57, 58-75. [CrossRef]

90. Carpenter, T.D.; Reimers, J.L.; Fretwell, P.Z. Internal auditors' fraud judgments: The benefits of brainstorming in groups. Audit. J. Pract. Theory 2011, 30, 211-224. [CrossRef]

91. Norman, C.S.; Rose, J.M.; Suh, I.S. The effects of disclosure type and audit committee expertise on chief audit executives' tolerance for financial misstatements. Account. Organ. Soc. 2011, 36, 102-108. [CrossRef]

92. Suh, I.; Sweeney, J.T.; Linke, K.; Wall, J.M. Boiling the frog slowly: The immersion of C-suite financial executives into fraud. J. Bus. Ethics 2020, 162, 645-673. [CrossRef]

93. Cohen, J.; Ding, Y.; Lesage, C.; Stolowy, H. Corporate fraud and managers' behavior: Evidence from the press. J. Bus. Ethics 2010, 95, 271-315. [CrossRef]

94. Cohen, J.; Ding, Y.; Lesage, C.; Stolowy, H. Media bias and the persistence of the expectation gap: An analysis of press articles on corporate fraud. J. Bus. Ethics 2017, 144, 637-659. [CrossRef]

95. Hobson, J.L.; Mayew, W.J.; Venkatachalam, M. Analyzing speech to detect financial misreporting. J. Account. Res. 2012, 50, 349-392. [CrossRef]

96. Dzuranin, A.C.; Mălăescu, I. The current state and future direction of IT audit: Challenges and opportunities. J. Inf. Syst. 2016, 30, 7-20. [CrossRef]

97. Pickard, M.D.; Cokins, G. From bean counters to bean growers: Accountants as data analysts-A customer profitability example. J. Inf. Syst. 2015, 29, 151-164. [CrossRef]

98. Li, C.; Haohao, S.; Ming, F. Research on the impact of artificial intelligence technology on accounting. J. Phys. Conf. Ser. 2019, 1486, 032042. [CrossRef]

99. Faccia, A.; Mosteanu, N.R. Accounting and blockchain technology: From double-entry to triple-entry. Bus. Manag. Rev. 2019, 10, 108-116.

100. Bao, Y.; Ke, B.; Li, B.; Yu, Y.J.; Zhang, J. Detecting accounting fraud in publicly traded US firms using a machine learning approach. J. Account. Res. 2020, 58, 199-235. [CrossRef]

101. Brown, N.C.; Crowley, R.M.; Elliott, W.B. What are you saying? Using topic to detect financial misreporting. J. Account. Res. 2020, 58, 237-291. [CrossRef]

102. Chen, J.; Cumming, D.; Hou, W.; Lee, E. CEO accountability for corporate fraud: Evidence from the split share structure reform in China. J. Bus. Ethics 2016, 138, 787-806. [CrossRef]

103. Liu, X. Corruption culture and corporate misconduct. J. Financ. Econ. 2016, 122, 307-327. [CrossRef]

104. Tan, D.T.; Chapple, L.; Walsh, K.D. Corporate fraud culture: Re-examining the corporate governance and performance relation. Account. Financ. 2017, 57, 597-620. [CrossRef]

105. DeZoort, F.T.; Harrison, P.D. Understanding auditors' sense of responsibility for detecting fraud within organizations. J. Bus. Ethics 2018, 149, 857-874. [CrossRef] 